\title{
Development of HIV drug resistance in a cohort of adults on first-line antiretroviral therapy in Tanzania during the stavudine era
}

Raphael Z Sangeda ( $\nabla$ sangeda@gmail.com )

Department of Pharmaceutical Microbiology, Muhimbili University of Health and Allied Sciences, Dar es Salaam, Tanzania https://orcid.org/0000-0002-

6574-5308

Perpétua Gómes

Centro Investigação Interdisciplinar Egas Moniz (CiiEM), Almada, Portugal https://orcid.org/0000-0003-3271-8255

Soo-Yon Rhee

Division of Infectious Diseases, Stanford University, Stanford, CA, USA https://orcid.org/0000-0002-1231-6542

\section{Fausta Mosha}

Communicable Diseases Cluster, AFRO Inter-Country Support Team, World Health Organization, Harare, Zimbabwe https://orcid.org/0000-0003-1319-8434

\section{Ricardo J. Camacho}

Center for Global Health and Tropical Medicine, Unidade de Microbiologia, Instituto de Higiene e Medicina Tropical, Universidade Nova de Lisboa, Lisbon,

Portugal. https://orcid.org/0000-0002-9129-3237

Eric Van Wijngaerden

Department of Microbiology, Immunology and Transplantation, University and University Hospitals KU Leuven, Leuven, Belgium

Eligius F. Lyamuya

Department of Microbiology and Immunology, Muhimbili University of Health and Allied Sciences, Dar es Salaam, Tanzania

Anne-Mieke Vandamme

KU Leuven - University of Leuven, Department of Microbiology, Immunology and Transplantation, Rega Institute for Medical Research, B-3000 Leuven, Belgium https://orcid.org/0000-0002-6594-2766

\section{Research Article}

Keywords: HIV-1, Drug resistance, Dar es Salaam, Tanzania, NNRTI, NRTI

Posted Date: November 19th, 2020

DOl: https://doi.org/10.21203/rs.3.rs-110477/v1

License: @ (i) This work is licensed under a Creative Commons Attribution 4.0 International License. Read Full License

Version of Record: A version of this preprint was published at Microbiology Research on November 12th, 2021. See the published version at https://doi.org/10.3390/microbiolres12040062. 


\section{Abstract}

As more HIV patients start combination antiretroviral therapy (CART), the emergence of HIV drug resistance (HIVDR) is inevitable. This will have consequences for the transmission of HIVDR, the success of ART, and the nature and trend of the epidemic. We recruited a cohort of 223 patients starting or continuing their first-line cART in Tanzania during the stavudine era in 2010. Patients were then followed up for one year. From those with a viral load test at baseline and follow-up time, $34 \%$ were failing virologically at the one-year endpoint. From 41 patients, protease and reverse transcriptase genotyping were successful. Eighteen samples were from therapy-naïve patients and 23 samples were taken under therapy either baseline for patients already under cART at study entry, or follow-up sample. The isolates were mostly subtype A, followed by C and D at $41.5 \%, 22 \%$ and $12.2 \%$ of the patients, respectively. No transmitted HIVDR was detected, as scored using the surveillance drug resistance mutations (DRMs) list. However, in 3 of the 18 samples from therapy-naïve patients, the clinical Rega interpretation algorithm scored 44D or 138A as non-nucleoside reverse transcriptase inhibitor (NNRTI) resistance-associated polymorphisms. The most observed nucleoside reverse transcriptase inhibitor (NRTI) mutation was $184 \mathrm{~V}$. The mutation was found in 16 patients causing resistance to lamivudine and emtricitabine. Nineteen patients had NNRTI resistance mutations, the most common of which was 103N observed in 8 patients. These high levels of resistance calls for regular drug resistance surveillance in Tanzania to control the emergence and transmission of HIVDR.

\section{Background}

The recent scale-up of combination antiretroviral therapy (CART) in resource-limited settings (RLS) has resulted in a significant reduction in morbidity and mortality among HIV and AIDS patients. The success of these programs stems from the population-based approach to provide affordable and simplified standard first- and second-line regimens recommended by the World Health Organization (WHO). Among the few ARVs that are available under such settings, a combination of two nucleoside reverse transcriptase inhibitors (NRTIs) and one non-nucleoside reverse transcriptase inhibitor (NNRTI) is used as firstline(World Health Organization, 2016). In a recent update, the WHO recommendations include a more potent dolutegravir (DTG), belonging to the class of integrase strand transfer inhibitors (INSTIs), along with two NRTIS backbone (World Health Organization, 2019). The standard second-line regimen consists of before DTG recommendation was lopinavir boosted with ritonavir as the only protease inhibitor (PI) recommended with 2 NRTIs. The main concern with these costly treatment programs is that they can compromise the utility of the first-line regimen by i) the low genetic barrier to resistance of NNRTIs, ii) long-term side effects such as toxicity, lipodystrophy and peripheral neuropathy that are associated with the use of stavudine, which was one of the main NRTI component of first-line therapy in many RLS, which increases the chances of non-adherence and iii) failure of first-line regimens due to lack of potency of ARV combinations, insufficient drug adherence and transmission of drug-resistant strains.

Although countries have scaled up the use of tenofovir, thymidine analogues such as stavudine or zidovudine are still in use in Sub Saharan Africa (Goodall et al., 2017).

In developed countries, the standard of care is to change treatment when the viral load becomes detectable, and guiding the next line therapy by assessing the susceptibility of patient isolates using genotypic assays to select ARV drugs, which can bring a successful treatment response. Several publicly available algorithms (Liu \& Shafer, 2006; Raposo \& Nobre, 2017; Van Laethem et al., 2002; Vercauteren \& Vandamme, 2006) are used to interpret the mutations. Prospective controlled studies have shown that patients whose physicians have access to HIV drug resistance (HIVDR) data, particularly genotypic resistance data, respond better to therapy than control patients of physicians without such access (Liu \& Shafer, 2006; Van Laethem \& Vandamme, 2006). These kinds of data have led several experts in North America and Europe to recommend HIVDR testing in the management of HIV-1 infected patients (Hirsch et al., 2008; Liu \& Shafer, 2006; Vandamme et al., 2011). In RLS, individuals are currently monitored using clinical and immunological criteria only because of the high cost of viral load assays and HIVDR genotyping. Whether or not HIVDR is to be expected, is monitored through population-based surveys of early warning indicators (EWI) predefined by the WHO. Factors monitored as EWI include antiretroviral therapy (ART) prescribing practices; patients lost to follow-up after initiation of ART; patients on appropriate first-line treatment at 12 months; on-time patient appointment keeping and ARV drug pick-ups; and ARV drug supply continuity. Optionally, other adherence measurements and HIV viral load suppression at 12 months may be collected (Bennett et al., 2012).

In Tanzania, patients return to care and treatment centers monthly for ARV refill and medical evaluation based on clinical symptoms and immunological progress. A few genotypic studies have only recently been conducted (Barabona et al., 2019; Hawkins et al., 2016; Johannessen et al., 2009; Somi et al., 2008) and the extent of resistance development during cART in Tanzania is mostly unknown. The objective of this study was to document the development of HIVDR during first-line therapy in Tanzania. We determined the HIV-1 protease and reverse transcriptase genotypic diversity and drug resistance mutations (DRMs) at study baseline and one-year follow-up, selected from our cohort, and for whom we had viral load measurements at study baseline or one year of follow-up.

\section{Methods}

\section{Cohort description}

Samples were collected during a prospective cohort study involving first-line ARV users at Amana district hospital care and treatment center (CTC) at the llala Municipality in Dar es Salaam, Tanzania, as previously described (Sangeda et al., 2018, 2014). Two hundred and fifty-four patients chosen randomly were consulted for inclusion in the cohort (as described previously and in Figure 1). Selection criteria were either starting cART or being on a first-line ART. Exclusion criteria were being below 18 years, pregnant, having opportunistic infections or malignancy. Thirty-one were excluded because of various reasons. A total of 223 patients were finally included, 26 of whom started cART at study entry and 197 were on cART for more than four months at study entry. 


\section{Virological outcome subset}

Patients with baseline or follow-up viral load measurements are shown in Figure 1.

Viral load measurements on samples of 210 patients that were on therapy for at least six months (EACS, 2019) were pooled together. In total, 354 viral load measurements were available for patients from this set of patients.

\section{Genotyping subset}

In total, 105 samples (Figure 1) had a detectable viral load at any one time. Ninety-five samples from 82 patients were sent for genotyping, after an error in packing10 samples during shipping.

\section{Data collection procedures}

\section{Treatment history and clinical data}

Treatment and clinical data of the patients were collected using a patient's history from manual and electronic medical records.

\section{Drawing of Blood Samples}

For CD4 count testing, viral load testing and genotyping, $10 \mathrm{ml}$ of blood was collected in EDTA tubes from each patient, at study baseline and one year later. Besides, patient CD4 counts were monitored at three-monthly intervals. Plasma samples were separated from cells by centrifugation and frozen at $-70^{\circ} \mathrm{C}$ within 24 hours. These samples were kept at the laboratory of Microbiology and Immunology, Muhimbili University of Health and Allied Sciences (MUHAS), Dar es Salaam, Tanzania.

\section{Viral load measurement}

Viral load testing was done using the Roche Taqman 2.0 system, the only assay available in the laboratory of Microbiology and Immunology (MUHAS) at the time of the study, which has a detection limit of $\leq 400$ copies $/ \mathrm{ml}$.

\section{Genotyping of patients' HIV isolates}

Samples were shipped to the Molecular Biology Laboratory, Centro Hospitalar de Lisboa, in Portugal for genotyping. HIV-1 genotyping was performed with the ViroSeq HIV-1 Genotyping System (Abbot Diagnostics) or an in-house system (Fokam et al., 2011). Protease (PR) and reverse transcriptase (RT) nucleotide sequences were analyzed with an ABI PRISM 3100 automated sequencer. The sequences were deposited into GenBank with accession numbers MN816754MN816797.

\section{Data storage and analysis}

RegaDB software (Libin et al., 2013) was used to store patient data along with the viral sequences. Data included patient treatment history indicating the duration of therapy and the actual drugs taken by each patient. Built-in tools were used to identify the HIV- 1 subtypes and circulating recombinant forms (CRFs), amino acid mutation lists, and drug resistance profiles. Subtypes were identified based on the Rega subtyping tool 3.0 (Pineda-Peña et al., 2013 ). Transmitted DRMs were assessed using the WHO updated list of surveillance DRMs (Bennett et al., 2009) at Stanford's calibrated population resistance tool (CPR). Genotypic susceptibility scores (GSS) were based on Rega HIVDR interpretation algorithm version 8.0.1 (Van Laethem et al., 2002) all of which are implemented in the RegaDB software. Each drug received a GSS score of 1 if susceptible except boosted PI scored 1.5; 0.5 if intermediate resistant for an NRTI, 0.25 for an NNRTI and 0.75 for a boosted PI. An isolate was scored 0 if resistant to the drug. Total GSS scores for the regimen used at the time of sampling and for the available second-line regimens were calculated as the cumulated score of the individual drugs.

Data stored in RegaDB was exported into an R statistical software package for further analysis, including descriptive statistics and mutation tables. Descriptive analyses included median, interquartile range (IQR) for numerical variables, frequencies and proportions for categorical variables were performed and tested for association using Fisher or Chi-square tests. For continuous variables, the Wilcoxon signed-rank test or Mann-Whitney' test for continuous values was used to test associations. HIVDR was defined as the presence of one DRM out of the following list (Johnson et al., 2013): RT 41L, 44D, 62V, 65R, 67N, 70R, 74I/V, 75I, 77L, 100I, 101P, 103N/S, 106A/M, 108I, 115F, 116Y, 118I, 138A/G/K/Q/R, 151M, 179L, 181C/V, 184I/V, 188C/H/L, 190A/S, 210W, 215F/Y, 219E/Q, 221Y, 225H, 227C and 230I/L for RT; protease10I/F/V, 11I, 16E, 20I/M/R/T/V, 24I, 30N, 33I/F/V, 34Q, 36I/L/V, 43T, 46I/L, 47A/V, 48V, 50V, 53L/Y, 54L/V, 54M/T/A, 60E, 62V, 63P, 64L/M/V, 69K/R, 71I/L/T/V, 73A/C/S/T, 74P, 76V, 77I, 82A/F/S/T, 84V, 85V, 88D/S, 89I/M/V, 90M and 93L/M.

The cut-off level of significance for all analyses was $P<0.05$. All statistical analyses were performed using the R-statistical package version 2.15 .1 ( $R$ Development Core Team, 2020). 


\section{Ethical Issues}

We addressed issues of patient confidentiality, benefits and risks to participating patients, justice, rights and respect that the patients deserve, and the study was approved by the Muhimbili University of Health and Allied Sciences (MUHAS) Research Ethics Committee (MU/DRP/AEC/VOL. XIII/140). Only patients who were willing to participate in the study and who signed informed consent were recruited into this study. Patient codes were used to de-link the patient data in databases. Patients did not receive any payments to motivate them to participate in the study.

\section{Results}

\section{Description of cohort regimens}

For those patients who were already on their first-line treatment at the start of the study, the distribution of various therapy regimens was as follows. A fixed combination of twice a day dose of Triomune-30, a co-formulation of stavudine (d4T), lamivudine (3TC) and nevirapine (NVP) was the commonly dispensed therapy to 101 (45.9\%) of all patients. One patient received d4T + 3TC + efavirenz (EFV), and 97 patients (44.1\%) were on Combivir (zidovudine (AZT) + 3TC) based therapy in combination with EFV, NVP or abacavir (ABC) in 54, 42 and 1 patient(s), respectively. During the one year follow-up, 13 patients had changed therapy for reasons of toxicities to the ARVs. Of the therapy changes described in Table 1 Two switched to zidovudine (AZT) and lamivudine (3TC) and 11 to tenofovir disoproxil fumarate (TDF) and emtricitabine (FTC) based therapies. In the former group, there was one virological failure compared to 2 in the latter group. These latter two patients failed to pick all or half of their ARV pharmacy refills during the follow-up and consequently developed at least one NNRTI mutation (See Table 1).

\section{Virological response data}

At one year of follow-up, longitudinal viral load measurements were available for 162 patients (Figure 1 ). The virological response for this set of patients with viral load measurement at both study baseline and follow-up of the study is summarized in Table 2. Briefly, of the 162 patients, 14 were therapy-naïve at recruitment and all had a detectable viral load, of the 148 with therapy experience at recruitment 18 (12.2\%) had a detectable viral load. At one year follow-up, 55 (34\%) of the 162 patients had a detectable viral load. Fifteen patients had a detectable viral load at both time points, only 2 of which were therapy-naïve at study entry.

Taking only the 210 patients that were on therapy for at least six months, a total of 354 viral load measurements were available. These patients had been on treatment for a median (IQR) of $32(22-44)$ months. Eighty $(22.6 \%)$ patients had a detectable viral load (see Figure 2). The median (IQR) duration of therapy in the various time windows was 10 (8.25-11), 18 (15-22), 31 (28-34) and 48 (41-56) months, for one, two, three and more than three years groups, respectively. The proportion of patients with detectable viral load was: $28.57 \%$ in year $1,13.86 \%$ in year $2,30.39 \%$ in year 3 , and $22.63 \%$ of those on therapy for more than three years. There was a significant positive correlation in the proportion of patients with detectable viral load with increasing exposure to therapy $(p$-value $=$ 0.03) (Figure 2).

\section{The success rate of genotyping}

Of the 105 samples with detectable viral load, 95 samples from 82 patients were available for genotyping, 47 from the study baseline and 48 from follow-up samples. Genotyping was successful in 44 of the 95 samples (46.3\%), obtained from 41 of the 82 patients. Of the successful samples, 18 were baseline samples from therapy-naïve patients (Table 3) and 26 were from 23 patients with treatment-experienced (Table 1) for more than four months (11 baseline samples, 15 follow-up samples, with only two patients both baseline and follow-up samples: patients number 27 and 35 ). For patient 27 by accident, two samples with a one-month interval were genotyped for the one year follow-up time point. Of the 18 patients that entered the study when drug-naïve and for whom baseline genotyping was successful, two were virologically failing at one year (Table 1). However, the genotyping of these two failing samples was not successful, probably due to sample degradation. Since the lab performing the assays had no problems with other batches of samples analyzed in the same run, even some with a viral load of a few hundred copies $/ \mathrm{ml}$, we ascribe this high failure rate to inappropriate storage conditions in the Tanzanian center. Indeed, power failure is a frequent problem, and it is not uncommon for freezers to go through several thawing cycles during the few years the samples were stored until genotyping could be performed.

The samples that were successfully genotyped had higher median viral loads $48,700(13,980-226,600)$ copies/ml than the ones that were not successful 2,449 $(824-31,000)$ copies/ml ( $p$-value <0.01). Viral loads were reassessed for four samples for which genotyping had failed and found undetectable or very low, suggesting sample deterioration indeed. As a quality check, baseline and follow-up samples in a few paired sequences were found to cluster together in phylogenetic trees, including appropriate controls (Lemey et al., 2005), confirming that at least these sequences were properly linked per patient.

\section{Subtype diversity}


The HIV subtype distribution of the isolates is shown in Figure 3. Subtype A was the dominant subtype in $41.5 \%$ of the patients, followed by $\mathrm{C}$ and $\mathrm{D}$ at $22 \%$ and $12.2 \%$, respectively.

\section{HIV drug resistance}

For the analyzed patients, the genotypic resistance profile and therapy changes during follow-up are shown in Table 1 and Table 3. No transmitted HIVDR was detected among the 18 available genotypes in patients that were starting therapy at recruitment. However, 44D or 138A, RT resistance-associated polymorphisms scored by the Rega algorithm, were detected in three patients. No genotype at follow-up was available for patients that initiated therapy at recruitment; they all had either undetectable viral load or a low viral load (Table 1). Taking baseline and follow-up samples together, at least one DRM (excluding PI polymorphisms) was observed in 19 (82.6\%) of the 23 therapy experienced patients with genotyping results. NNRTI and NRTI mutations were found in the baseline sample of 19 and 16 of these patients, respectively. Dual NNRTI and NRTI mutations were observed in 16 patients.

Taking all samples together, the most frequently observed RT mutation was $184 \mathrm{~V}$ (Table 1 and Table 5) followed by $103 \mathrm{~N}$. No major PI mutation was found in any of the samples, but all except one patient harboured some minor PI mutations, which is to be expected considering the subtypes. For the two patients with baseline and follow-up genotype, resistance evolution was observed. In one, the mutations $184 \mathrm{~V}$ and $190 \mathrm{~A}$ occurred first, followed by the accumulation of TAMs $(41 \mathrm{~L}, 67 \mathrm{~N}, 70 \mathrm{R}, 75 \mathrm{I}$, and $215 \mathrm{~F})$. In the second patient, mutations $67 \mathrm{~N}, 70 \mathrm{R}, 181 \mathrm{C}$ and $184 \mathrm{~V}$ were observed first and followed by the addition of $215 \mathrm{~F}$ and $219 \mathrm{E}$. All observed resistance mutations were related to the therapy received by the respective patients. The polymorphisms $44 \mathrm{D}$ and $138 \mathrm{~A}$ were not observed in patients with therapy experience at study entry.

The Rega algorithm scored a median genotypic susceptibility score (GSS) of 3 for isolates from therapy-naïve patients. For patients on therapy for more than four months, median GSS (IQR) was $1.0(0.5$ - 2.0) (Table 4). Most patients had NNRTI resistance, both against NVP and EFV (Figure 4). A large proportion of patients had resistance to NRTIs: $69.6 \%, 69.6 \%, 21.7 \%, 21.7 \%$ and $8.7 \%$ of the treated patients with genotyping results conveying resistance to the drugs lamivudine (3TC), emtricitabine (FTC), zidovudine (AZT), stavudine (D4T) and abacavir (ABC), respectively (Table 5). The median (IQR) calculated GSS for standard second-line ABC + FTC + boosted lopinavir (LPV/r) and tenofovir disoproxil fumarate (TDF) + FTC + LPV/r therapies was 2.5 (2.0-3.5) and 2.5 (2.53.5), respectively (Table 4).

\section{Discussion}

In this prospective cohort study in Tanzania, we followed-up patients on first-line treatment and reported on primary and acquired drug resistance. Although the design of the study was prospective, the failure to obtain a genotype for $50 \%$ of our viral load positive samples, and successes heavily biased towards samples with higher viral load, has as a result that we can merely report on the resistance evolution found.

The most prevalent genotypes among the isolates from Tanzanian patients were subtyped A followed by $\mathrm{C}$ and $\mathrm{D}$. This is consistent with studies conducted earlier (Arroyo et al., 2004, 2005; Hoelscher et al., 2001; Kiwelu et al., 2003; Mosha et al., 2011; Nyombi, Holm-Hansen, Kristiansen, Bjune, \& Müller, 2008; Nyombi, Kristiansen, Bjune, Müller, \& Holm-Hansen, 2008; Nyombi, Nkya, et al., 2008), but we now confirm this in a higher number of patients. The proportion of unique recombinant forms (URFs) and circulating recombinant forms (CRFs) was substantial at nineteen percent of all isolates. Further, investigation of these recombinants is required because of their implications in vaccine design strategies.

Encouragingly, in the 18 therapy-naïve patients that were starting therapy and for whom genotyping was available, we did not find any transmitted DRM. Initial transmitted drug resistance (TDR) surveys by WHO in the middle- and low-income countries indicate low-level TDR (<5\%) in the majority of surveillance sites and moderate (5-15\%) levels of TDR in 17\% of sites (Bertagnolio, Kelley, Hassani, Obeng-Aduasare, \& Jordan, 2011). Our study, although not following the WHO TDR protocol, confirms a low level as previously reported by others (Mosha et al., 2011; Somi et al., 2008). However, two patients had in the reverse transcriptase the amino acid 138A and one patient had 44D. Both mutations are excluded in the WHO list of surveillance DRMs (Bennett et al., 2009) because they also occur as natural polymorphism in drug-naïve patients. None of the treatment-experienced patients harboured isolates with these two mutations. The amino acid 44D has an accessory role in increasing NNRTI resistance if it occurs with thymidine analogue mutations (TAMS) (Cozzi-Lepri et al., 2005). This mutation occurs in about $1 \%$ of isolates from untreated patients but in a significantly higher proportion of patients receiving NRTI (Shafer \& Schapiro, 2008). Amino acid 138A has no or little consequence for nevirapine or efavirenz if it occurs on its own (Shafer \& Schapiro, 2008). However, it is an important resistance mutation for rilpivirine (Johnson et al., 2013), a drug that is not yet available in Tanzania. This mutation has been found in other naïve patients from Tanzania (Kasang et al., 2011). E138A has been reported as the most prevalent rilpivirine mutation in as high as 3\% of drug-naïve patients in the developed world (Lambert-Niclot et al., 2013). The mutation was twice as common in a set of viral isolates from various non-B subtypes as compared to a set of subtype B isolates. Although not unexpected, it is worrying to see a high prevalence of $1.1 \%$, also in our cohort. However, for our patients, none of these resistance-related polymorphisms has a clinical impact on first-line therapy; they all had a GSS of 3.

Only $22.6 \%$ of the patients on their first-line cART for at least six months were failing virologically, and the failure rate was significantly correlated with the duration of therapy. Similar levels have been shown in other resource-limited countries at $24 \%$ and $33 \%$ of patients treated for a duration of 12 and 24 months 
(Barth, van der Loeff, Schuurman, Hoepelman, \& Wensing, 2010). In patients with a successful genotype, the majority (82.6\%) harboured DRMs. We found several RT DRMs, $69.7 \%$ to NRTIs, $82.6 \%$ to NNRTIs and $69.7 \%$ dual NRTI/NNRTI resistance, consistent with their first-line treatment which contained zidovudine (AZT) or stavudine (D4T), lamivudine (3TC) and nevirapine (NVP) or efavirenz (EFV) and with other reports in resource-limited settings (Barth et al., 2010). In each case, resistance was related to the drugs received. Of the mutations found in protease, all were so-called "minor DRMs", recognized as natural polymorphisms in the respective subtypes. It has been suggested that polymorphisms in non-B subtypes can affect both the magnitude of resistance conveyed by major mutations as well as the propensity to acquire specific resistance mutations (Camacho \& Vandamme, 2007; Wainberg \& Brenner, 2012). However, our numbers are too small to make any conclusions in this regard.

Among the successful genotypes, the most common mutation was $184 \mathrm{~V}$, which was present in most patients on treatment. This mutation confers resistance to lamivudine and emtricitabine. It is also believed to delay the appearance of TAMs (Johnson et al., 2013). When it occurs together with TAMs, it may cause abacavir $(A B C)$ resistance, one of the second-line drugs in Tanzania. TAMs were also present in a substantial proportion of patients. In one of the patients with more than one follow-up sample, the TAMs occurred later than $184 \mathrm{~V}$. The abundance of the mutation $103 \mathrm{~N}$ that confers resistance to efavirenz and nevirapine is of significant concern since these NNRTIs are the mainstay of first-line therapy. Other observed NNRTI mutations were 181C and 190A. All patients failing with resistance had high-level resistance to NNRTIs. Similar mutations were observed in patients from the north part of the country (Johannessen et al., 2009). In our study, the use of stavudine did not lead to the mutation K65R. This makes it possible for these patients to switch to tenofovir disoproxil fumarate (TDF)based regimens as a second-line choice. Other studies have indicated the propensity of mutation K65R in subtype C (Theys et al., 2013; Wainberg \& Brenner, 2012), but this was not evident from our cohort study.

Concerning protease inhibitor resistance mutations, the polymorphism $36 \mathrm{I}, 69 \mathrm{~K}$ and $89 \mathrm{M}$ were most prevalent, found in one third or more of all patients. $36 \mathrm{I}$ is a common polymorphism in non-B subtypes, while $89 \mathrm{M}$ occurs in $\mathrm{A}, \mathrm{C}, \mathrm{F}, \mathrm{G}, \mathrm{AE}$ and $\mathrm{AG}$ subtypes. The $89 \mathrm{M}$ polymorphism can lead to the M89I/L mutation that confers resistance to Pls in various subtypes (Ana B Abecasis et al., 2006; Ana Barroso Abecasis et al., 2005; Wainberg \& Brenner, 2012).

The presence of such a scale of DRMs among failing patients is a critical alert for the country to prepare for regimens for the second-line. If not controlled, these resistance mutations can spread through transmission, compromising first-line therapy in new infections. The consequence of the resistance is evident in this cohort. Many patients were failing with dual-class resistance. Isolates were resistant to 3TC and NRTIs, which are the essential components of first-line therapy. That means that these patents need to switch to second-line such as ABC or TDF combined with boosted lopinavir (LPV/r) or atazanavir (Kasang et al., 2011; Ministry of Health Community Development Gender Elderly and Children, 2017). We tried to predict the susceptibility of the failing genotypes to the second-line regimen, where ABC or TDF are combined with FTC and LPV/r. Because of delayed switching, mutations had already accumulated and GSS to potential second-line therapies was suboptimal (<3) for most failing patients. Taking into account that fully active boosted PI therapy is scored GSS=1.5 according to the Rega algorithm used, second-line therapy was already compromised for some patients (GSS $\leq 2)$. Noteworthy, three patients were already failing with HIVDR on TDF and FTC based therapy, to which they had been switched for toxicity reasons. These patients had not picked their pharmacy refills on time. This suggests that patients who are switched to this regimen should be monitored closely for adherence; its failure may jeopardize the future of second-line therapy in general since they are all based on TDF and FTC.

While relatively few patients are failing virologically in our cohort, prevalence and level of HIVDR in these patients are high, hardly nine years after cART scaleup started in Tanzania, and we ascribe this to lack of virological monitoring. Therefore, apart from the surveillance of HIVDR, it is vital for Tanzania and other RLS to build local capacity to implement viral load and HIVDR testing to guide changes in the standard regimens, reduce the risk of emergence and transmission of HIVDR among patients on treatment, and to implement long-term successful cART programs effectively. Part of the data gathered in this work will be utilized to help build such local capacity and also to develop, test and improve the HIVDR interpretation-models. The kind of data gathered here, stored in electronic databases such as the free and open-source RegaDB (Libin et al., 2013), will allow HIV and AIDS policymakers and health care stakeholders to make informed decisions and interventions to mitigate the emergence of drug-resistant HIV isolates among patients.

\section{Conclusion}

These high levels of resistance among virologically failing patients call for regular drug resistance surveillance in Tanzania to control the emergence and transmission of drug resistance in the population.

\section{List Of Abbreviations}

3TC: lamivudine

ABC: abacavir

ARVs: antiretrovirals

AZT: zidovudine

CART: combination antiretroviral therapy

CRFs: circulating recombinant forms

D4T: stavudine 
DRMs: drug resistance mutations

DTG: Dolutegravir

EFV: efavirenz

EWl: early warning indicators

FTC: emtricitabine

GSS: genotypic susceptibility score

HIVDR: HIV drug resistance

LPV/r: ritonavir-boosted lopinavir

NNRTI: non-nucleoside reverse transcriptase inhibitor

NRTI: nucleoside reverse transcriptase inhibitor

NVP: nevirapine

PI: protease inhibitor

TAMS: thymidine analogue mutations

TDF: tenofovir disoproxil fumarate

URFs: unique recombinant forms

\section{Declarations}

\section{Ethics approval and consent to participate}

We addressed issues of patient confidentiality, benefits and risks to participating patients, justice, rights and respect that the patients deserve, and the study was approved by the Muhimbili University of Health and Allied Sciences (MUHAS) Research Ethics Committee. Only patients who were willing to participate in the study and who signed informed consent were recruited into this study. Patient codes were used to de-link the patient data in databases. Patients did not receive any payments to motivate them to participate in the study.

\section{Consent for publication}

Not applicable

\section{Availability of data and material}

The dataset analyzed during the current study is available from the corresponding author on request.

\section{Funding}

RZS acknowledges the support of the Belgian Technical Cooperation (BTC) for funding his PhD research.

\section{Authors' contributions}

RZS designed the study, conducted the interviews, performed data and statistical analysis, and wrote the first draft of the manuscript; PG, FM, and RJC supervised laboratory work and manuscript review; EFL, EVW, and AMV supervised the overall study implementation and manuscript development process. All authors read and approved the final manuscript.

\section{Acknowledgements}

RZS acknowledges the support of the Belgian Technical Cooperation (BTC) for funding part of this study. A-MV was supported by the Fonds voor Wetenschappelijk Onderzoek Vlaanderen (grant K8.012.12N). Part of this study was funded by Sida under Muhimbili University of Health and Allied Sciences (MUHAS) small grants scheme, by the Fonds voor Wetenschappelijk Onderzoek Vlaanderen (grant G.06.11.09) and by the European Community's Seventh Framework Programme (FP7/2007-2013) under the project "Collaborative HIV and Anti-HIV Drug Resistance Network (CHAIN)" grant agreement no 223131. 
We are thankful to the patients for cooperating and participating in the study and to the CTC manager, doctors, nurses, counsellors, tracking officers and auxiliary support staff who made the meetings with the patients possible and much easier.

\section{References}

Abecasis, Ana B, Deforche, K., Bacheler, L. T., McKenna, P., Carvalho, A. P., Gomes, P., ... Camacho, R. J. (2006). Investigation of baseline susceptibility to protease inhibitors in HIV-1 subtypes C, F, G and CRF02_AG. Antiviral Therapy, 11(5), 581-589. Retrieved from

http://www.ncbi.nlm.nih.gov/pubmed/16964826

Abecasis, Ana Barroso, Deforche, K., Snoeck, J., Bacheler, L. T., McKenna, P., Carvalho, A. P., ... Vandamme, A.-M. (2005). Protease mutation M89I/V is linked to therapy failure in patients infected with the HIV-1 non-B subtypes C, F or G. AIDS (London, England), 19(16), 1799-1806.

https://doi.org/10.1097/01.aids.0000188422.95162.b7

Arroyo, M. A., Hoelscher, M., Sanders-Buell, E., Herbinger, K.-H., Samky, E., Maboko, L., ... McCutchan, F. E. (2004). HIV type 1 subtypes among blood donors in the Mbeya region of southwest Tanzania. AIDS Research and Human Retroviruses, 20(8), 895-901. https://doi.org/10.1089/0889222041725235

Arroyo, M. A., Hoelscher, M., Sateren, W., Samky, E., Maboko, L., Hoffmann, O., ... McCutchan, F. E. (2005). HIV-1 diversity and prevalence differ between urban and rural areas in the Mbeya region of Tanzania. AIDS (London, England), 19(14), 1517-1524. https://doi.org/10.1097/01.aids.0000183515.14642.76

Barabona, G., Mahiti, M., Masoud, S., Mbelele, P., Mgunya, A. S., Minja, L., ... Ueno, T. (2019). Pre-treatment and acquired HIV drug resistance in Dar es Salaam, Tanzania in the era of tenofovir and routine viral load monitoring. Journal of Antimicrobial Chemotherapy, 74(10), 3016-3020.

https://doi.org/10.1093/jac/dkz272

Barth, R. E., van der Loeff, M. F. S., Schuurman, R., Hoepelman, A. I., \& Wensing, A. M. (2010). Virological follow-up of adult patients in antiretroviral treatment programmes in sub-Saharan Africa: a systematic review. The Lancet Infectious Diseases, 10(3), 155-166. https://doi.org/10.1016/S1473-3099(09)70328-7

Bennett, D. E., Camacho, R. J., Otelea, D., Kuritzkes, D. R., Fleury, H., Kiuchi, M., ... Shafer, R. W. (2009). Drug resistance mutations for surveillance of transmitted HIV-1 drug-resistance: 2009 update. PloS One, 4(3), e4724. https://doi.org/10.1371/journal.pone.0004724

Bennett, D. E., Jordan, M. R., Bertagnolio, S., Hong, S. Y., Ravasi, G., McMahon, J. H., ... Kelley, K. F. (2012). HIV drug resistance early warning indicators in cohorts of individuals starting antiretroviral therapy between 2004 and 2009: World Health Organization global report from 50 countries. Clinical Infectious Diseases: An Official Publication of the Infectious Diseases Society of America, 54 Supp/ 4(suppl 4), S280-9. https://doi.org/10.1093/cid/cis207

Bertagnolio, S., Kelley, K., Hassani, A., Obeng-Aduasare, Y., \& Jordan, M. R. (2011). Surveillance of Transmitted and Acquired HIV Drug Resistance Using WHO Surveys in Resource-limited Settings. 18th Conference on Retroviruses and Opportunistic Infections.

Camacho, R. J., \& Vandamme, A.-M. (2007). Antiretroviral resistance in different HIV-1 subtypes: impact on therapy outcomes and resistance testing interpretation. Current Opinion in HIV and AIDS, 2(2), 123-129. Retrieved from http://www.ncbi.nlm.nih.gov/pubmed/19372877

Cozzi-Lepri, A., Ruiz, L., Loveday, C., Phillips, A. N., Clotet, B., Reiss, P., ... Lundgren, J. D. (2005). Thymidine analogue mutation profiles: factors associated with acquiring specific profiles and their impact on the virological response to therapy. Antiviral Therapy, 10(7), 791-802. Retrieved from

http://www.ncbi.nlm.nih.gov/pubmed/16312176

EACS. (2019). European AIDS Clinical Society guidelines version 10 - November 2019.

Fokam, J., Salpini, R., Santoro, M. M., Cento, V., D’Arrigo, R., Gori, C., ... Takou, D. (2011). Performance evaluation of an in-house human immunodeficiency virus type-1 protease-reverse transcriptase genotyping assay in Cameroon. Archives of Virology, 156(7), 1235-1243. https://doi.org/10.1007/s00705-011-0982-3

Goodall, R. L., Dunn, D. T., Nkurunziza, P., Mugarura, L., Pattery, T., Munderi, P., ... Gupta, R. K. (2017). Rapid accumulation of HIV-1 thymidine analogue mutations and phenotypic impact following prolonged viral failure on zidovudine-based first-line ART in sub-Saharan Africa. Journal of Antimicrobial Chemotherapy, 72(5), 1450-1455. https://doi.org/10.1093/jac/dkw583

Hawkins, C., Ulenga, N., Liu, E., Aboud, S., Mugusi, F., Chalamilla, G., ... Fawzi, W. (2016). HIV virological failure and drug resistance in a cohort of Tanzanian HIV-infected adults. The Journal of Antimicrobial Chemotherapy, 71(7), 1966-1974. https://doi.org/10.1093/jac/dkw051

Hirsch, M. S., Günthard, H. F., Schapiro, J. M., Brun-Vézinet, F., Clotet, B., Hammer, S. M., ... Richman, D. D. (2008). Antiretroviral drug resistance testing in adult HIV-1 infection: 2008 recommendations of an International AIDS Society-USA panel. Clinical Infectious Diseases, 47(2), $266-285$.

https://doi.org/10.1086/589297

Hoelscher, M., Kim, B., Maboko, L., Mhalu, F., von Sonnenburg, F., Birx, D. L., \& McCutchan, F. E. (2001). High proportion of unrelated HIV-1 intersubtype recombinants in the Mbeya region of southwest Tanzania. AIDS, 15(12), 1461-1470. https://doi.org/10.1097/00002030-200108170-00002

Johannessen, A., Naman, E., Kivuyo, S. L., Kasubi, M. J., Holberg-Petersen, M., Matee, M. I., ... Bruun, J. N. (2009). Virological efficacy and emergence of drug resistance in adults on antiretroviral treatment in rural Tanzania. BMC Infectious Diseases, 9(1), 108. https://doi.org/10.1186/1471-2334-9-108 
Johnson, V. A., Calvez, V., Gunthard, H. F., Paredes, R., Pillay, D., Shafer, R. W., ... Richman, D. D. (2013). Update of the drug resistance mutations in HIV-1: March 2013. Topics in Antiviral Medicine, 21(1), 6-14. Retrieved from http://www.ncbi.nlm.nih.gov/pubmed/23596273

Kasang, C., Kalluvya, S., Majinge, C., Stich, A., Bodem, J., Kongola, G., ... Weissbrich, B. (2011). HIV drug resistance (HIVDR) in antiretroviral therapy-naïve patients in Tanzania not eligible for WHO threshold HIVDR survey is dramatically high. PloS One, 6(8), e23091. https://doi.org/10.1371/journal.pone.0023091

Kiwelu, I. E., Renjifo, B., Chaplin, B., Sam, N., Nkya, W. M., Shao, J., ... Essex, M. (2003). HIV type 1 subtypes among bar and hotel workers in Moshi, Tanzania. AIDS Research and Human Retroviruses, 19(1), 57-64. https://doi.org/10.1089/08892220360473970

Lambert-Niclot, S., Charpentier, C., Storto, A., Fofana, D. B., Soulié, C., Fourati, S., ... Marcelin, A.-G. (2013). Prevalence of pre-existing resistance-associated mutations to rilpivirine, emtricitabine and tenofovir in antiretroviral-naive patients infected with B and non-B subtype HIV-1 viruses. The Journal of Antimicrobial Chemotherapy, 68(6), 1237-1242. https://doi.org/10.1093/jac/dkt003

Lemey, P., Derdelinckx, I., Rambaut, A., Van Laethem, K., Dumont, S., Vermeulen, S., ... Vandamme, A.-M. (2005). Molecular footprint of drug-selective pressure in a human immunodeficiency virus transmission chain. Journal of Virology, 79(18), 11981-11989. https://doi.org/10.1128/JVI.79.18.11981-11989.2005

Libin, P., Beheydt, G., Deforche, K., Imbrechts, S., Ferreira, F., Van Laethem, K., ... Lacore, P. (2013). RegaDB: Community-driven data management and analysis for infectious diseases. Bioinformatics, in press(11), 1477-1480. https://doi.org/10.1093/bioinformatics/btt162

Liu, T. F., \& Shafer, R. W. (2006). Web resources for HIV type 1 genotypic-resistance test interpretation. Clinical Infectious Diseases: An Official Publication of the Infectious Diseases Society of America, 42(11), 1608-1618. https://doi.org/10.1086/503914

Ministry of Health Community Development Gender Elderly and Children. (2017). National Guidelines for the management of HIV and AIDS in Tanzania. Retrieved November 16, 2020, from http://www.nacp.go.tz/download/national-guidelines-for-the-management-of-hiv-and-aids/

Mosha, F., Urassa, W., Aboud, S., Lyamuya, E. F., Sandstrom, E., Bredell, H., \& Williamson, C. (2011). Prevalence of genotypic resistance to antiretroviral drugs in treatment-naive youths infected with diverse HIV type 1 subtypes and recombinant forms in Dar es Salaam, Tanzania. AIDS Research and Human Retroviruses, 27(4), 377-382. https://doi.org/10.1089/aid.2010.0113

Nyombi, B. M., Holm-Hansen, C., Kristiansen, K. I., Bjune, G., \& Müller, F. (2008). Prevalence of reverse transcriptase and protease mutations associated with antiretroviral drug resistance among drug-naïve HIV-1 infected pregnant women in Kagera and Kilimanjaro regions, Tanzania. AIDS Research and Therapy, 5(1), 13. https://doi.org/10.1186/1742-6405-5-13

Nyombi, B. M., Kristiansen, K. I., Bjune, G., Müller, F., \& Holm-Hansen, C. (2008). Diversity of human immunodeficiency virus type 1 subtypes in Kagera and Kilimanjaro regions, Tanzania. AIDS Research and Human Retroviruses, 24(6), 761-769. https://doi.org/10.1089/aid.2007.0311

Nyombi, B. M., Nkya, W. M., Barongo, L., Bjune, G., Kristiansen, K. I., Müller, F., \& Holm-Hansen, C. (2008). Evolution of human immunodeficiency virus type 1 serotypes in northern Tanzania: a retrospective study. APMIS, 116(6), 507-514. https://doi.org/10.1111/j.1600-0463.2008.00996.X

Pineda-Peña, A. A.-C., Faria, N. R., Imbrechts, S., Libin, P., Abecasis, A. B., Deforche, K., ... Gómez-López, A. (2013). Automated subtyping of HIV-1 genetic sequences for clinical and surveillance purposes: performance evaluation of the new Rega version 3 and seven other tools. Infection, Genetics and Evolution, in press. https://doi.org/10.1016/j.meegid.2013.04.032

R Development Core Team. (2020). R: A Language and Environment for Statistical Computing. Vienna, Austria. Retrieved from http://www.r-project.org/

Raposo, L. M., \& Nobre, F. F. (2017). Ensemble Classifiers for Predicting HIV-1 Resistance from Three Rule-Based Genotypic Resistance Interpretation Systems. Journal of Medical Systems, 41(10), 155. https://doi.org/10.1007/s10916-017-0802-8

Sangeda, R. Z., Mosha, F., Aboud, S., Kamuhabwa, A., Chalamilla, G., Vercauteren, J., ... Vandamme, A.-M. (2018). Predictors of non adherence to antiretroviral therapy at an urban HIV care and treatment center in Tanzania. Drug, Healthcare and Patient Safety, Volume 10, 79-88.

https://doi.org/10.2147/DHPS.S143178

Sangeda, R. Z., Mosha, F., Prosperi, M., Aboud, S., Vercauteren, J., Camacho, R. J., ... Vandamme, A.-M. (2014). Pharmacy refill adherence outperforms selfreported methods in predicting HIV therapy outcome in resource-limited settings. BMC Public Health, 14(1), 1035. https://doi.org/10.1186/1471-2458-14-1035

Shafer, R. W., \& Schapiro, J. M. (2008). HIV-1 drug resistance mutations: an updated framework for the second decade of HAART. AIDS Reviews, 10 (2), 67-84. Retrieved from http://www.pubmedcentral.nih.gov/articlerender.fcgi?artid=2547476\&tool=pmcentrez\&rendertype=abstract

Somi, G. R., Kibuka, T., Diallo, K., Tuhuma, T., Bennett, D. E., Yang, C., ... Kassim, S. (2008). Surveillance of transmitted HIV drug resistance among women attending antenatal clinics in Dar es Salaam, Tanzania. Antiviral Therapy, 13 Suppl 2(SUPPL. 2), 77-82. Retrieved from http://www.ncbi.nlm.nih.gov/pubmed/18575194

Theys, K., Vercauteren, J., Snoeck, J., Zazzi, M., Camacho, R. J., Torti, C., ... Abecasis, a B. (2013). HIV-1 subtype is an independent predictor of reverse transcriptase mutation K65R in HIV-1 patients treated with combination antiretroviral therapy including tenofovir. Antimicrobial Agents and Chemotherapy, 57(2), 1053-1056. https://doi.org/10.1128/AAC.01668-12 
Van Laethem, K., De Luca, A., Antinori, A., Cingolani, A., Perna, C. F., \& Vandamme, A.-M. (2002). A genotypic drug resistance interpretation algorithm that significantly predicts therapy response in HIV-1-infected patients. Antiviral Therapy, 7(2), 123-129. Retrieved from

http://www.ncbi.nlm.nih.gov/pubmed/12212924

Van Laethem, K., \& Vandamme, A.-M. (2006). Interpreting resistance data for HIV-1 therapy management-know the limitations. AIDS Reviews, 8(1), 37-43. Retrieved from http://www.ncbi.nlm.nih.gov/pubmed/16736950

Vandamme, A.-M., Camacho, R. J., Ceccherini-Silberstein, F., De Luca, A., Palmisano, L., Paraskevis, D., ... Sönnerborg, A. (2011). European recommendations for the clinical use of HIV drug resistance testing: 2011 update. AIDS Reviews, 13(2), 77-108. Retrieved from http://www.ncbi.nlm.nih.gov/pubmed/21587341

Vercauteren, J., \& Vandamme, A.-M. (2006). Algorithms for the interpretation of HIV-1 genotypic drug resistance information. Antiviral Research, 71(2-3), 335342. https://doi.org/10.1016/j.antiviral.2006.05.003

Wainberg, M. A., \& Brenner, B. G. (2012). The Impact of HIV Genetic Polymorphisms and Subtype Differences on the Occurrence of Resistance to Antiretroviral Drugs. Molecular Biology International, 2012, 256982. https://doi.org/10.1155/2012/256982

World Health Organization. (2016). Consolidated guidelines on the use of antiretroviral drugs for treating and preventing HIV infection: recommendations for a public health approach, 2nd ed. World Health Organization. Retrieved November 15, 2020, from https://apps.who.int/iris/handle/10665/208825

World Health Organization. (2019). Update of recommendations on first- and second-line antiretroviral regimens. Retrieved November 16, 2020, from https://www.who.int/hiv/pub/arv/arv-update-2019-policy/en/

\section{Tables}

Table 1: Characteristics of patients and the mutations found in RT and PR regions of HIV isolates from patients on therapy for more than four months at study entry 


\begin{tabular}{|c|c|c|c|c|c|c|c|c|c|c|c|c|c|}
\hline $\begin{array}{l}\text { Patient } \\
\#\end{array}$ & $\begin{array}{l}\text { Sequence } \\
\text { ID }\end{array}$ & $\begin{array}{l}\text { Age } \\
\text { at } \\
\text { study } \\
\text { entry }\end{array}$ & Gender & Subtypet & $\begin{array}{l}\text { Therapy } \\
\text { duration* }\end{array}$ & $\begin{array}{l}\text { Pharmacy } \\
\text { refill } \\
\text { adherence } \\
(\%)\end{array}$ & $\begin{array}{l}\text { Study } \\
\text { baseline } \\
\text { Therapy }\end{array}$ & $\begin{array}{l}\text { Study } \\
\text { baseline } \\
\text { Log VL }\end{array}$ & $\begin{array}{l}\text { Last } \\
\text { therapy }\end{array}$ & $\begin{array}{l}\text { Follow- } \\
\text { up } \\
\text { Log VL }\end{array}$ & $\begin{array}{l}\text { NNRTI } \\
\text { mutations }\end{array}$ & $\begin{array}{l}\text { NRTI } \\
\text { mutations }\end{array}$ & $\begin{array}{l}\mathrm{P} \\
\mathrm{p} \\
\mathrm{S} \\
\mathrm{rt}\end{array}$ \\
\hline 19 & F001 & 33 & $\mathrm{~F}$ & URF & 34 & 92.62 & $\begin{array}{l}\text { AZT, } \\
\text { 3TC, } \\
\text { NVP }\end{array}$ & 4.56 & $\begin{array}{l}\text { no } \\
\text { change }\end{array}$ & $\leq 2.60$ & none & none & $\begin{array}{l}1 \\
6\end{array}$ \\
\hline 20 & W0141 & 54 & $M$ & $\mathrm{D}$ & 37 & 97.27 & $\begin{array}{l}\text { d4T, } \\
\text { 3TC, } \\
\text { NVP }\end{array}$ & $\leq 2.60$ & $\begin{array}{l}\text { no } \\
\text { change }\end{array}$ & 2.82 & none & none & $\begin{array}{l}1 \\
6\end{array}$ \\
\hline 21 & W0067 & 50 & $\mathrm{~F}$ & $A$ & 31 & 56.73 & $\begin{array}{l}\text { d4T, } \\
\text { 3TC, } \\
\text { NVP }\end{array}$ & $\leq 2.60$ & $\begin{array}{l}\text { no } \\
\text { change }\end{array}$ & 4.18 & none & none & $\begin{array}{l}1 \\
6\end{array}$ \\
\hline 22 & F110 & 28 & $\mathrm{~F}$ & $A$ & 6 & 100 & $\begin{array}{l}\text { AZT, } \\
\text { 3TC, } \\
\text { EFV }\end{array}$ & 5.94 & $\begin{array}{l}\text { no } \\
\text { change }\end{array}$ & NA & none & none & $\begin{array}{l}1 \\
8\end{array}$ \\
\hline 23 & F189 & 36 & $M$ & D & 22 & 0 & $\begin{array}{l}\text { AZT, } \\
\text { 3TC, } \\
\text { NVP }\end{array}$ & 4.71 & $\begin{array}{l}\text { TDF, } \\
\text { FTC, } \\
\text { EFV }\end{array}$ & 4.18 & $103 N$ & none & 2 \\
\hline 24 & F134 & 33 & $\mathrm{~F}$ & C & 16 & 0 & $\begin{array}{l}\text { d4T, } \\
\text { 3TC, } \\
\text { NVP }\end{array}$ & 3.34 & $\begin{array}{l}\text { no } \\
\text { change }\end{array}$ & NA & $190 \mathrm{~A}$ & none & $\begin{array}{l}2 \\
8\end{array}$ \\
\hline 25 & F141 & 37 & $\mathrm{~F}$ & $C$ & 4 & 100 & $\begin{array}{l}\text { AZT, } \\
\text { 3TC, } \\
\text { EFV }\end{array}$ & 5.05 & $\begin{array}{l}\text { no } \\
\text { change }\end{array}$ & NA & $103 N$ & none & $\begin{array}{l}3 \\
9\end{array}$ \\
\hline 26 & F144 & 41 & $\mathrm{~F}$ & URF & 66 & 22.62 & $\begin{array}{l}\text { d4T, } \\
\text { 3TC, } \\
\text { NVP }\end{array}$ & 4.26 & $\begin{array}{l}\text { no } \\
\text { change }\end{array}$ & NA & $181 \mathrm{C}$ & $184 \mathrm{~V}$ & 1 \\
\hline 27 & F176 & 29 & $M$ & $A$ & 26 & 100 & $\begin{array}{l}\text { d4T, } \\
\text { 3TC, } \\
\text { NVP }\end{array}$ & 4.03 & $\begin{array}{l}\text { AZT, } \\
\text { 3TC, } \\
\text { NVP }\end{array}$ & & $190 \mathrm{~A}$ & $184 \mathrm{~V}$ & $\begin{array}{l}1 \\
8\end{array}$ \\
\hline 27 & W0037 & & & & 40 & & & & & 5.43 & $190 \mathrm{~A}$ & $\begin{array}{l}67 \mathrm{~N}, 75 \mathrm{I}, \\
184 \mathrm{~V} \\
215 \mathrm{~F} \\
219 \mathrm{E}\end{array}$ & $\begin{array}{l}1 \\
8\end{array}$ \\
\hline 27 & W0116 & & & & 41 & & & & & 4.56 & $190 \mathrm{~A}$ & $\begin{array}{l}41 \mathrm{~L}, 67 \mathrm{~N}, \\
70 \mathrm{R}, 75 \mathrm{I}, \\
184 \mathrm{~V}, \\
215 \mathrm{~F}\end{array}$ & $\begin{array}{l}1 \\
8\end{array}$ \\
\hline 28 & W0065 & 32 & $M$ & (A2) & 18 & 92.14 & $\begin{array}{l}\text { AZT, } \\
\text { 3TC, } \\
\text { EFV }\end{array}$ & $\leq 2.60$ & $\begin{array}{l}\text { no } \\
\text { change }\end{array}$ & 4.67 & $103 N$ & $184 \mathrm{~V}$ & $\begin{array}{l}1 \\
8\end{array}$ \\
\hline 29 & W0021 & 55 & $\mathrm{~F}$ & $\begin{array}{l}\text { CRF } \\
\text { 10_CD }\end{array}$ & 44 & 91.9 & $\begin{array}{l}\text { AZT, } \\
\text { 3TC, } \\
\text { NVP }\end{array}$ & $\leq 2.60$ & $\begin{array}{l}\text { no } \\
\text { change }\end{array}$ & 3.97 & $103 \mathrm{~N}$ & $\begin{array}{l}184 \mathrm{~V} \\
215 \mathrm{Y}\end{array}$ & 6 \\
\hline 30 & F064 & 35 & $\mathrm{~F}$ & C & 40 & 100 & $\begin{array}{l}\text { d4T, } \\
\text { 3TC, } \\
\text { NVP }\end{array}$ & 3.13 & $\begin{array}{l}\text { no } \\
\text { change }\end{array}$ & NA & $\begin{array}{l}181 C \\
221 Y\end{array}$ & $184 \mathrm{~V}$ & $\begin{array}{l}2 \\
9\end{array}$ \\
\hline 31 & W0079 & 47 & $M$ & $\begin{array}{l}\text { CRF } \\
10 \_C D\end{array}$ & 53 & 100 & $\begin{array}{l}\text { d4T, } \\
\text { 3TC, } \\
\text { NVP }\end{array}$ & 5.10 & $\begin{array}{l}\text { no } \\
\text { change }\end{array}$ & 5.86 & $190 \mathrm{~A}$ & $\begin{array}{l}184 \mathrm{~V}, \\
215 \mathrm{~F}\end{array}$ & 6 \\
\hline 32 & W0127 & 40 & M & C & 30 & 100 & $\begin{array}{l}\text { d4T, } \\
\text { 3TC, } \\
\text { NVP }\end{array}$ & $\leq 2.60$ & $\begin{array}{l}\text { no } \\
\text { change }\end{array}$ & 4.77 & $\begin{array}{l}181 \mathrm{~V} \\
221 \mathrm{Y}\end{array}$ & $184 \mathrm{~V}$ & $\begin{array}{l}2 \\
6\end{array}$ \\
\hline 33 & W0019 & 37 & $\mathrm{~F}$ & URF & 19 & 50.72 & $\begin{array}{l}\text { AZT, } \\
\text { 3TC, } \\
\text { EFV }\end{array}$ & $\leq 2.60$ & $\begin{array}{l}\text { no } \\
\text { change }\end{array}$ & 5.55 & $\begin{array}{l}103 \mathrm{~N} \\
108 \mathrm{I}\end{array}$ & 75I, 184V & $\begin{array}{l}3 \\
6\end{array}$ \\
\hline 34 & W0066 & 32 & $\mathrm{~F}$ & C & 26 & 36.76 & $\begin{array}{l}\text { d4T, } \\
\text { 3TC, } \\
\text { NVP }\end{array}$ & 3.24 & $\begin{array}{l}\text { no } \\
\text { change }\end{array}$ & 5.79 & $\begin{array}{l}103 \mathrm{~N}, \\
108 \mathrm{l} \\
138 \mathrm{~A}\end{array}$ & $184 \mathrm{~V}$ & $\begin{array}{l}1 \\
9\end{array}$ \\
\hline 35 & F003 & 33 & $\mathrm{~F}$ & $A$ & 10 & 84.97 & $\begin{array}{l}\text { d4T, } \\
\text { 3TC, } \\
\text { NVP }\end{array}$ & 4.27 & $\begin{array}{l}\text { no } \\
\text { change }\end{array}$ & 5.45 & $181 \mathrm{C}$ & $\begin{array}{l}67 \mathrm{~N}, \\
70 \mathrm{R}, 184 \mathrm{~V}\end{array}$ & $\begin{array}{l}2 \\
8\end{array}$ \\
\hline
\end{tabular}




\begin{tabular}{|c|c|c|c|c|c|c|c|c|c|c|c|c|c|}
\hline 35 & W0108 & & & & 25 & & & & & & $181 \mathrm{C}$ & $\begin{array}{l}67 \mathrm{~N}, 70 \mathrm{R}, \\
184 \mathrm{~V} \\
215 \mathrm{~F} \\
219 \mathrm{E}\end{array}$ & $\begin{array}{l}2 \\
8\end{array}$ \\
\hline 36 & W0158 & 39 & $\mathrm{~F}$ & A & 70 & 54.66 & $\begin{array}{l}\text { d4T, } \\
3 \mathrm{TC} \text {, } \\
\text { NVP }\end{array}$ & $\leq 2.60$ & $\begin{array}{l}\text { TDF, } \\
\text { FTC, } \\
\text { EFV }\end{array}$ & 5.21 & $181 \mathrm{C}$ & $\begin{array}{l}67 \mathrm{~N}, 70 \mathrm{R}, \\
184 \mathrm{~V} \\
215 \mathrm{~F} \\
219 \mathrm{E}\end{array}$ & $\begin{array}{l}2 \\
8\end{array}$ \\
\hline 37 & F068 & 26 & $M$ & URF & 36 & 28.71 & $\begin{array}{l}\text { d4T, } \\
3 \mathrm{TC} \text {, } \\
\text { NVP }\end{array}$ & 4.53 & $\begin{array}{l}\text { no } \\
\text { change }\end{array}$ & NA & $\begin{array}{l}103 \mathrm{~N}, \\
181 \mathrm{C}\end{array}$ & $\begin{array}{l}70 \mathrm{R}, \\
184 \mathrm{~V} \\
219 \mathrm{Q}, \\
225 \mathrm{H}\end{array}$ & $\begin{array}{l}3 \\
8\end{array}$ \\
\hline 38 & W0120 & 32 & $M$ & C & 30 & 54.26 & $\begin{array}{l}\text { d4T, } \\
3 \mathrm{TC}, \\
\text { NVP }\end{array}$ & 4.45 & $\begin{array}{l}\text { no } \\
\text { change }\end{array}$ & 5.33 & $\begin{array}{l}\text { 118I, } \\
181 \mathrm{C}\end{array}$ & $\begin{array}{l}67 \mathrm{~N} \\
184 \mathrm{~V} \\
210 \mathrm{~W} \\
215 \mathrm{Y}\end{array}$ & $\begin{array}{l}1 \\
8\end{array}$ \\
\hline 39 & W0054 & 24 & $\mathrm{~F}$ & $A$ & 33 & 80.63 & $\begin{array}{l}\text { d4T, } \\
3 \mathrm{TC} \text {, } \\
\text { NVP }\end{array}$ & 4.61 & $\begin{array}{l}\text { no } \\
\text { change }\end{array}$ & 4.85 & $\begin{array}{l}181 \mathrm{I} \\
190 \mathrm{~A}\end{array}$ & $\begin{array}{l}67 \mathrm{~N} \\
116 \mathrm{Y} \\
151 \mathrm{M}, \\
184 \mathrm{~V}\end{array}$ & $\begin{array}{l}1 \\
6\end{array}$ \\
\hline 40 & W0062 & 35 & $\mathrm{~F}$ & URF & 72 & 70.53 & $\begin{array}{l}\text { TDF, } \\
\text { FTC, } \\
\text { EFV }\end{array}$ & 4.99 & $\begin{array}{l}\text { no } \\
\text { change }\end{array}$ & 4.99 & $\begin{array}{l}103 \mathrm{~N}, \\
108 \mathrm{I}, \\
138 \mathrm{Q}, \\
179 \mathrm{~L}\end{array}$ & $\begin{array}{l}41 \mathrm{~L}, 84 \mathrm{~V} \\
215 \mathrm{~F}\end{array}$ & 3 \\
\hline 41 & F183 & 35 & M & A & 37 & 100 & $\begin{array}{l}\mathrm{d} 4 \mathrm{~T}, \\
3 \mathrm{TC}, \\
\text { NVP }\end{array}$ & 3.91 & $\begin{array}{l}\text { no } \\
\text { change }\end{array}$ & 5.21 & $\begin{array}{l}138 Q \\
190 A\end{array}$ & $\begin{array}{l}67 \mathrm{~N}, 70 \mathrm{R}, \\
184 \mathrm{~V} \\
219 \mathrm{E} \\
219 \mathrm{Q}\end{array}$ & 3 \\
\hline
\end{tabular}

*Sequence IDs starting with $\mathrm{F}$ were sampled at study entry and W code at follow-up

† URF: unique recombinant forms, such as CRF 10_CD/D; A1/C; C/D, and D/A.

$\mathrm{NRTI}$ = nucleoside reverse transcriptase inhibitor; NNRTI = non-nucleoside reverse transcriptase inhibitor; $\mathrm{PI}=$ protease inhibitor; $\mathrm{NA}=\mathrm{Not}$ applicable/available

3TC = lamivudine, $\mathrm{AZT}=$ zidovudine, $\mathrm{D} 4 \mathrm{~T}=$ stavudine, $\mathrm{FTC}=$ emtricitabine, $\mathrm{TDF}=$ tenofovir disoproxil fumarate, $\mathrm{EFV}=$ efavirenz, $\mathrm{NVP}=$ nevirapine.

All therapy switches were due to toxicity. Patients 19 and 23 had received D4T, 3TC and NVP before study entry but were changed to AZT, 3TC and NVP for toxicity reasons (peripheral neuropathy). Patient 40 had been on D4T, 3TC and NVP before study entry and was switched to TDF, FTC and EFV for toxicity reasons (lipodystrophy). During the follow-up of one year, therapy was changed as indicated for patients 23 due to anaemia, for 27 due to peripheral neuropathy and for 36 due to lipodystrophy.

Patient 33 and 36 did not pick up their drugs on time for the whole year.

Table 2: Viral load among study patients, listed according to therapy experience for 162 patients with both study baseline and follow-up viral load pair.

$\mathrm{VL}=$ Viral load; IQR=Interquartile range

\begin{tabular}{|c|c|c|c|c|c|c|}
\hline \multirow[b]{3}{*}{$\begin{array}{l}\text { Time of therapy } \\
\text { initiation }\end{array}$} & \multirow[b]{3}{*}{$\begin{array}{l}\text { Number of } \\
\text { patients }\end{array}$} & \multirow[b]{3}{*}{$\begin{array}{l}\text { Duration of therapy at study entry Median } \\
\text { months (IQR) }\end{array}$} & \multicolumn{3}{|c|}{ Detectable viral load } & \\
\hline & & & \multicolumn{2}{|c|}{ At study entry } & \multicolumn{2}{|c|}{ At one year follow-up } \\
\hline & & & $\mathrm{N}(\%)$ & $\begin{array}{l}\text { Log VL median } \\
\text { (IQR) }\end{array}$ & $\mathrm{N}(\%)$ & $\begin{array}{l}\text { Log VL median } \\
\text { (IQR) }\end{array}$ \\
\hline At study entry & 14 & 0 & $\begin{array}{l}14 \\
(100 \%)\end{array}$ & $5.1(4.9-5.6)$ & $\stackrel{2}{(14.3 \%)}$ & $4.4(4.1-4.6)$ \\
\hline Before study entry & 148 & $25(18-36)$ & $\begin{array}{l}18 \\
(12.2 \%)\end{array}$ & $4.4(3.5-4.7)$ & $\begin{array}{l}53 \\
(35.8 \\
\%)\end{array}$ & $3.9(2.9-4.8)$ \\
\hline
\end{tabular}

Table 3: Characteristics of patients and the mutations found in the RT and PR region from HIV isolates of the patients starting therapy at study entry 


\begin{tabular}{|c|c|c|c|c|c|c|c|c|c|c|}
\hline $\begin{array}{l}\text { Patent } \\
\#\end{array}$ & $\begin{array}{l}\text { Sequence } \\
\text { ID }\end{array}$ & $\begin{array}{l}\text { Age at } \\
\text { study } \\
\text { entry }\end{array}$ & Gender & Subtypet & $\begin{array}{l}\text { Pharmacy } \\
\text { refill } \\
\text { adherence } \\
(\%)\end{array}$ & $\begin{array}{l}\text { Therapy* (in } \\
\text { addition to } \\
\text { AZT+3TC) }\end{array}$ & $\begin{array}{l}\text { Log VL at } \\
\text { study } \\
\text { baseline }\end{array}$ & $\begin{array}{l}\text { Log VL } \\
\text { at one } \\
\text { year }\end{array}$ & $\begin{array}{l}\text { NNRTI resistance- } \\
\text { related } \\
\text { polymorphisms }\end{array}$ & $\begin{array}{l}\text { PI resistance- } \\
\text { related } \\
\text { polymorphisms }\end{array}$ \\
\hline 1 & N001 & 29 & $\mathrm{~F}$ & $\begin{array}{l}\text { CRF } \\
10 \_C D\end{array}$ & NA & EFV & 4.74 & NA & none & $36 I, 63 P$ \\
\hline 2 & N002 & 32 & $\mathrm{~F}$ & A & 100 & EFV & 5.94 & $\leq 2.60$ & none & $\begin{array}{l}10 \mathrm{I}, 36 \mathrm{I}, 69 \mathrm{~K} \\
89 \mathrm{M}\end{array}$ \\
\hline 3 & N003 & 26 & $\mathrm{~F}$ & A & 100 & EFV & 5.81 & NA & $138 \mathrm{~A}$ & $\begin{array}{l}36 \mathrm{I}, 62 \mathrm{~V}, 69 \mathrm{~K} \\
89 \mathrm{M}\end{array}$ \\
\hline 4 & N004 & 35 & M & A & 77.1 & EFV & 5.06 & NA & $138 \mathrm{~A}$ & $\begin{array}{l}20 \mathrm{I}, 36 \mathrm{I}, 64 \mathrm{M}, \\
69 \mathrm{~K}, 89 \mathrm{M}\end{array}$ \\
\hline 5 & N006 & 35 & $\mathrm{~F}$ & A & 95.84 & NVP & 5.12 & $\leq 2.60$ & $44 \mathrm{D}$ & $36 \mathrm{I}, 69 \mathrm{~K}, 89 \mathrm{M}$ \\
\hline 6 & N007 & 35 & M & URF & 100 & NVP & 3.31 & NA & none & $36 \mathrm{I}, 69 \mathrm{~K}, 89 \mathrm{M}$ \\
\hline 7 & N008 & 30 & $\mathrm{~F}$ & A & 93.29 & NVP & 4.79 & 4.72 & none & $\begin{array}{l}\text { 10I, 16E, 36I, } \\
69 \mathrm{~K}, 77 \mathrm{I}, 89 \mathrm{M}\end{array}$ \\
\hline 8 & N010 & 34 & $\mathrm{~F}$ & $A$ & 81.02 & EFV & 4.32 & $\leq 2.60$ & none & \\
\hline 9 & N011 & 42 & M & $\mathrm{D}$ & 91.47 & EFV & 6.00 & $\leq 2.60$ & none & $10 \mathrm{~V}, 63 \mathrm{P}, 64 \mathrm{~V}$ \\
\hline 10 & N012 & 38 & $\mathrm{~F}$ & URF & 93.38 & EFV & 5.74 & $\leq 2.60$ & none & $64 \mathrm{~V}$ \\
\hline 11 & N013 & 54 & M & D & 100 & EFV & 4.23 & NA & none & $64 \mathrm{M}, 77 \mathrm{I}$ \\
\hline 12 & N015 & 55 & M & $A$ & 97.39 & NVP & 5.47 & $\leq 2.60$ & none & $\begin{array}{l}111,36 \mathrm{I}, 63 \mathrm{P}, \\
69 \mathrm{~K}, 89 \mathrm{M} / \mathrm{I}\end{array}$ \\
\hline 13 & N016 & 52 & M & C & 92.57 & EFV & 5.65 & $\leq 2.60$ & none & 36I, 89M, 93L \\
\hline 14 & N017 & 32 & $M$ & $\mathrm{C}$ & 100 & EFV & 4.93 & $\leq 2.60$ & none & $\begin{array}{l}36 \mathrm{l}, 69 \mathrm{~K}, 89 \mathrm{M}, \\
93 \mathrm{~L}\end{array}$ \\
\hline 15 & N018 & 33 & $\mathrm{~F}$ & $\mathrm{D}$ & 100 & EFV & 5.05 & $\leq 2.60$ & none & $64 \mathrm{~V}, 77 \mathrm{I}$ \\
\hline 16 & N019 & 32 & M & $\mathrm{C}$ & 48.19 & EFV & 5.56 & NA & none & $\begin{array}{l}16 \mathrm{E}, 36 \mathrm{I}, 69 \mathrm{~K} \\
89 \mathrm{M}, 93 \mathrm{~L}\end{array}$ \\
\hline 17 & N020 & 56 & $\mathrm{~F}$ & A & 70.45 & EFV & 5.58 & NA & none & $\begin{array}{l}20 \mathrm{R}, 36 \mathrm{I}, 64 \mathrm{~L}, \\
69 \mathrm{~K}, 89 \mathrm{M}\end{array}$ \\
\hline 18 & N022 & 31 & $\mathrm{~F}$ & A & 84.87 & EFV & 5.16 & $\leq 2.60$ & none & $\begin{array}{l}\text { 10I, 111, 36I, } \\
63 \mathrm{P}, 69 \mathrm{~K}, 89 \mathrm{M}\end{array}$ \\
\hline
\end{tabular}

*None of these patients changed regimen for the entire follow-up period

† URF: unique recombinant forms, such as see Figure 3.

$\mathrm{NNRTI}=$ non-nucleoside reverse transcriptase inhibitor; $\mathrm{PI}=$ protease inhibitor; $\mathrm{NA}=$ Not available;

3TC = lamivudine, $\mathrm{AZT}$ = zidovudine, $\mathrm{EFV}=$ efavirenz, NVP = nevirapine.

No nucleoside reverse transcriptase inhibitor resistance mutation was found; Genotypic Susceptibility Score for all patients was 3

Table 4: Genotypic susceptibility score

Genotypic susceptibility of the current regimen and expected second-line regimen in genotypes from patients on antiretroviral therapy for more than four months at study entry 


\begin{tabular}{|c|c|c|c|c|c|c|c|}
\hline \multirow[b]{2}{*}{ Patient\# } & \multirow[b]{2}{*}{$\begin{array}{l}\text { Sequence } \\
\text { ID }\end{array}$} & \multirow[b]{2}{*}{ Resistance to NRTIs } & \multirow[b]{2}{*}{$\begin{array}{l}\text { Intermediate resistance to } \\
\text { NRTIs }\end{array}$} & \multirow[b]{2}{*}{$\begin{array}{l}\text { Resistance to } \\
\text { NNRTIs }\end{array}$} & \multirow{2}{*}{$\begin{array}{l}\begin{array}{l}\text { GSS of } \\
\text { regimen }\end{array} \\
\text { At sampling }\end{array}$} & \multicolumn{2}{|c|}{ GSS of potential second-line } \\
\hline & & & & & & $\begin{array}{l}\mathrm{ABC}+\mathrm{FTC}+ \\
\mathrm{LPV} / \mathrm{r}\end{array}$ & $\begin{array}{l}\text { TDF + FTC + } \\
\mathrm{LPV} / \mathrm{r}\end{array}$ \\
\hline 19 & F001 & none & none & none & 3 & 3.5 & 3.5 \\
\hline 20 & W0141 & none & none & none & 3 & 3.5 & 3.5 \\
\hline 21 & W0067 & none & none & none & 3 & 3.5 & 3.5 \\
\hline 22 & F110 & none & AZT, D4T & none & 3 & 3.5 & 3.5 \\
\hline 23 & F189 & none & none & EFV, NVP & 2 & 3.5 & 3.5 \\
\hline 24 & F134 & none & none & EFV, NVP & 2 & 3.5 & 3.5 \\
\hline 25 & $\mathrm{~F} 141$ & none & none & EFV, NVP & 2 & 3.5 & 3.5 \\
\hline 26 & F144 & 3TC, FTC & none & EFV, NVP & 1 & 2.5 & 2.5 \\
\hline 27 & F176 & 3TC, FTC & none & EFV, NVP & 1 & 2.5 & 2.5 \\
\hline 27 & w0037 & 3TC, AZT, D4T, FTC & $A B C$ & EFV, NVP & 0 & 2 & 2.5 \\
\hline 27 & W0116 & $\begin{array}{l}\text { 3TC, ABC, AZT, D4T, } \\
\text { FTC }\end{array}$ & TDF & EFV, NVP & 0 & 1.5 & 2 \\
\hline 28 & W0065 & 3TC, FTC & none & EFV, NVP & 1 & 2.5 & 2.5 \\
\hline 29 & w0021 & ЗТC, FTC & none & EFV, NVP & 1 & 2.5 & 2.5 \\
\hline 30 & F064 & 3TC, FTC & none & EFV, NVP & 1 & 2.5 & 2.5 \\
\hline 31 & W0079 & 3TC, FTC & none & EFV, NVP & 1 & 2.5 & 2.5 \\
\hline 32 & W0127 & 3TC, FTC & none & EFV, NVP & 1 & 2.5 & 2.5 \\
\hline 33 & W0019 & 3TC, FTC & none & EFV, NVP & 1 & 2.5 & 2.5 \\
\hline 34 & w0066 & 3TC, FTC & none & EFV, NVP & 1 & 2.5 & 2.5 \\
\hline 35 & F003 & ЗТC, FTC & ABC, AZT, D4T & EFV, NVP & 0.5 & 2 & 2.5 \\
\hline 35 & W0108 & $\begin{array}{l}\text { 3TC, ABC, AZT, D4T, } \\
\text { FTC }\end{array}$ & TDF & EFV, NVP & 0 & 1.5 & 2 \\
\hline 36 & W0158 & $\begin{array}{l}\text { 3TC, ABC, AZT, D4T, } \\
\text { FTC }\end{array}$ & TDF & EFV, NVP & 0 & 1.5 & 2 \\
\hline 37 & F068 & 3TC, FTC & ABC, AZT, D4T & EFV, NVP & 0.5 & 2 & 2.5 \\
\hline 38 & W0120 & 3TC, FTC & $\mathrm{ABC}, \mathrm{AZT}, \mathrm{D} 4 \mathrm{~T}$ & EFV, NVP & 0.5 & 2 & 2.5 \\
\hline 39 & W0054 & $\begin{array}{l}\text { 3TC, ABC, AZT, D4T, } \\
\text { FTC }\end{array}$ & none & EFV, NVP & 0 & 1.5 & 2.5 \\
\hline 40 & W0062 & $3 \mathrm{TC}, \mathrm{D} 4 \mathrm{~T}, \mathrm{FTC}$ & $A B C, A Z T$ & EFV, NVP & 1 & 2 & 2.5 \\
\hline 41 & F183 & 3TC, AZT, FTC & $\mathrm{ABC}, \mathrm{D} 4 \mathrm{~T}$ & EFV, NVP & 0.5 & 2 & 2.5 \\
\hline
\end{tabular}

NA = Not applicable/available; NRTI = nucleoside reverse transcriptase inhibitor; NNRTI = non-nucleoside reverse transcriptase inhibitor

3TC = lamivudine, ABC = abacavir, AZT = zidovudine, D4T = stavudine, FTC = emtricitabine, TDF = tenofovir disoproxil fumarate, EFV = efavirenz, NVP = nevirapine, ATV/r = boosted atazanavir, LPV/r = boosted lopinavir

Samples F176, W0037 and W0116 from patient \# 27 the first was taken at study entry and the last two after one year follow-up at one month interval.

Table 5: Prevalence of resistance mutations or natural polymorphisms scored as related to resistance in reverse transcriptase and protease regions among patients with therapy experience at study entry. Only the last sample was counted if more than one sample was available. NRTI = nucleoside reverse transcriptase inhibitor; NNRTI = non-nucleoside reverse transcriptase inhibitor; $\mathrm{PI}=$ Protease Inhibitor 


\begin{tabular}{|llllll|}
\hline \multicolumn{2}{|l}{ Amino acid } & & & & \\
\hline NRTI & $\%$ & NNRTI & $\%$ & PI & $\%$ \\
\hline $184 \mathrm{~V}$ & 69.57 & $103 \mathrm{~N}$ & 34.78 & $36 \mathrm{I}$ & 82.61 \\
\hline $67 \mathrm{~N}$ & 26.09 & $181 \mathrm{C}$ & 26.09 & $69 \mathrm{~K}$ & 78.26 \\
\hline $70 \mathrm{R}$ & 21.74 & $190 \mathrm{~A}$ & 21.74 & $89 \mathrm{M}$ & 60.87 \\
\hline $215 \mathrm{~F}$ & 21.74 & $108 \mathrm{I}$ & 13.04 & $20 \mathrm{R}$ & 39.13 \\
\hline $219 \mathrm{E}$ & 13.04 & $138 \mathrm{Q}$ & 8.7 & $16 \mathrm{E}$ & 34.78 \\
\hline $219 \mathrm{Q}$ & 8.7 & $221 \mathrm{Y}$ & 8.7 & $93 \mathrm{~L}$ & 30.43 \\
\hline $215 \mathrm{Y}$ & 8.7 & $118 \mathrm{I}$ & 4.35 & $63 \mathrm{P}$ & 21.74 \\
\hline $41 \mathrm{~L}$ & 8.7 & $138 \mathrm{~A}$ & 4.35 & $64 \mathrm{~V}$ & 17.39 \\
\hline $75 \mathrm{I}$ & 8.7 & $179 \mathrm{~L}$ & 4.35 & $10 \mathrm{~V}$ & 8.7 \\
\hline $151 \mathrm{M}$ & 4.35 & $181 \mathrm{I}$ & 4.35 & $10 \mathrm{I}$ & 4.35 \\
\hline $116 \mathrm{Y}$ & 4.35 & $181 \mathrm{~V}$ & 4.35 & $36 \mathrm{~L}$ & 4.35 \\
\hline $210 \mathrm{~W}$ & 4.35 & $225 \mathrm{H}$ & 4.35 & $62 \mathrm{~V}$ & 4.35 \\
\hline & & & & $64 \mathrm{~L}$ & 4.35 \\
\hline & & & & $89 \mathrm{I}$ & 4.35 \\
\hline
\end{tabular}

\section{Figures}

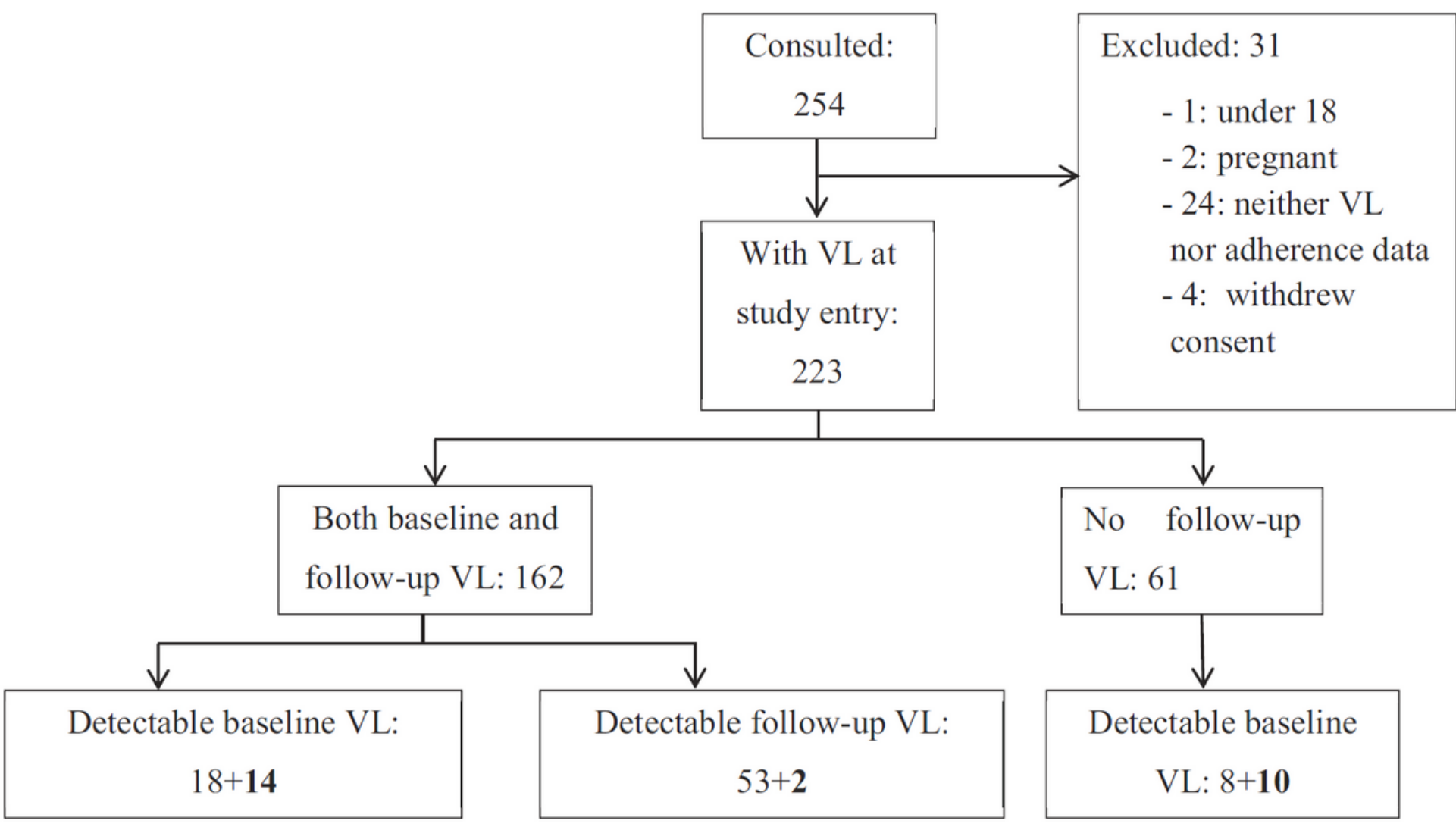

Figure 1

Patients sampling flowchart Starts with patients invited to participate in the study cohort. A total of 105 patients with detectable viral load (VL) are shown in the boxes at the bottom. In bold is the number of patients who started therapy at study entry. The others were already on therapy for at least four months. 


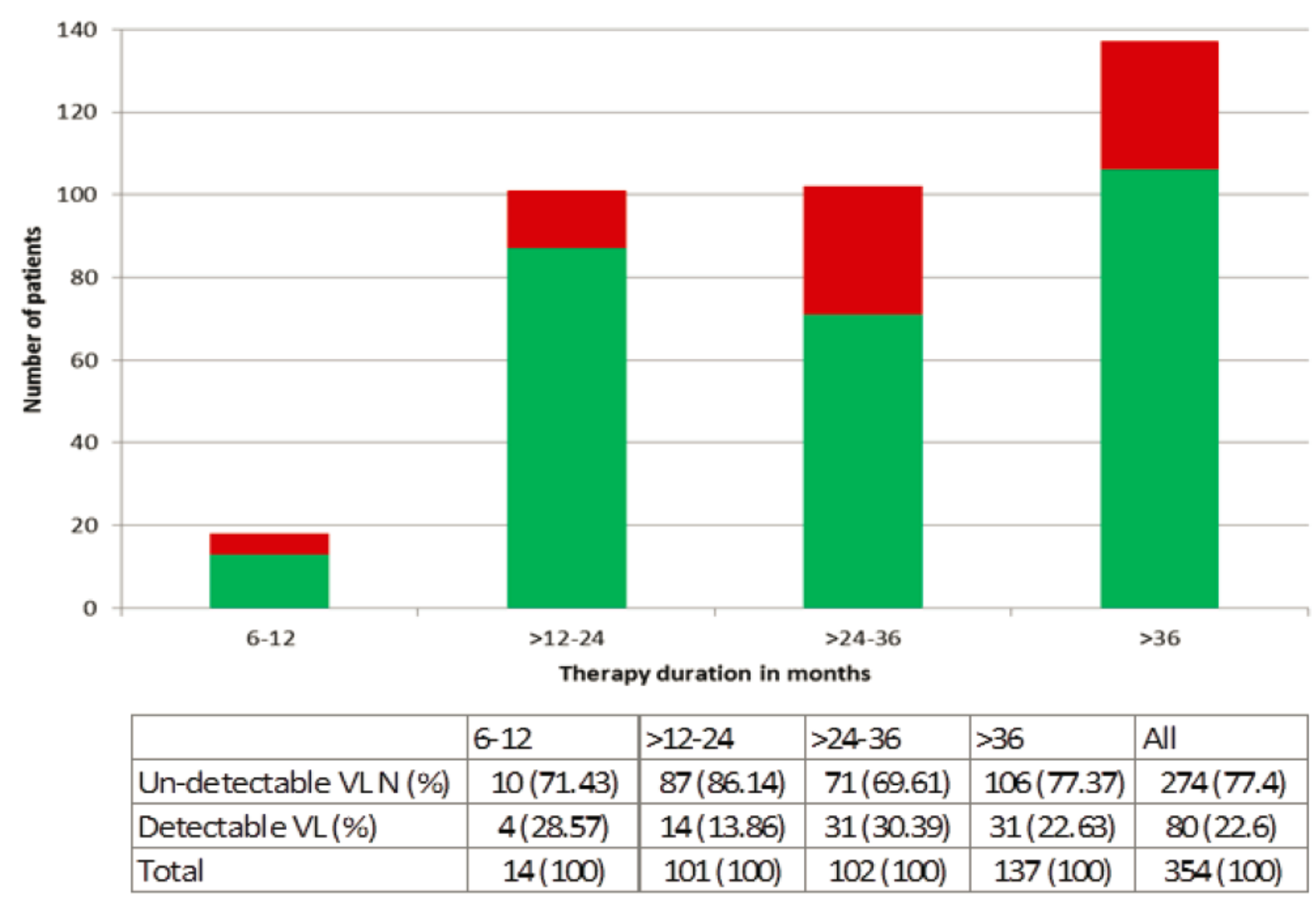

\section{Figure 2}

Proportion of patients with successful treatment at different time intervals after start of first-line treatment. (undetectable viral load on therapy can be considered successful treatment only for patients $\geq 6$ months on therapy, EACS guidelines (EACS, 2019)). 


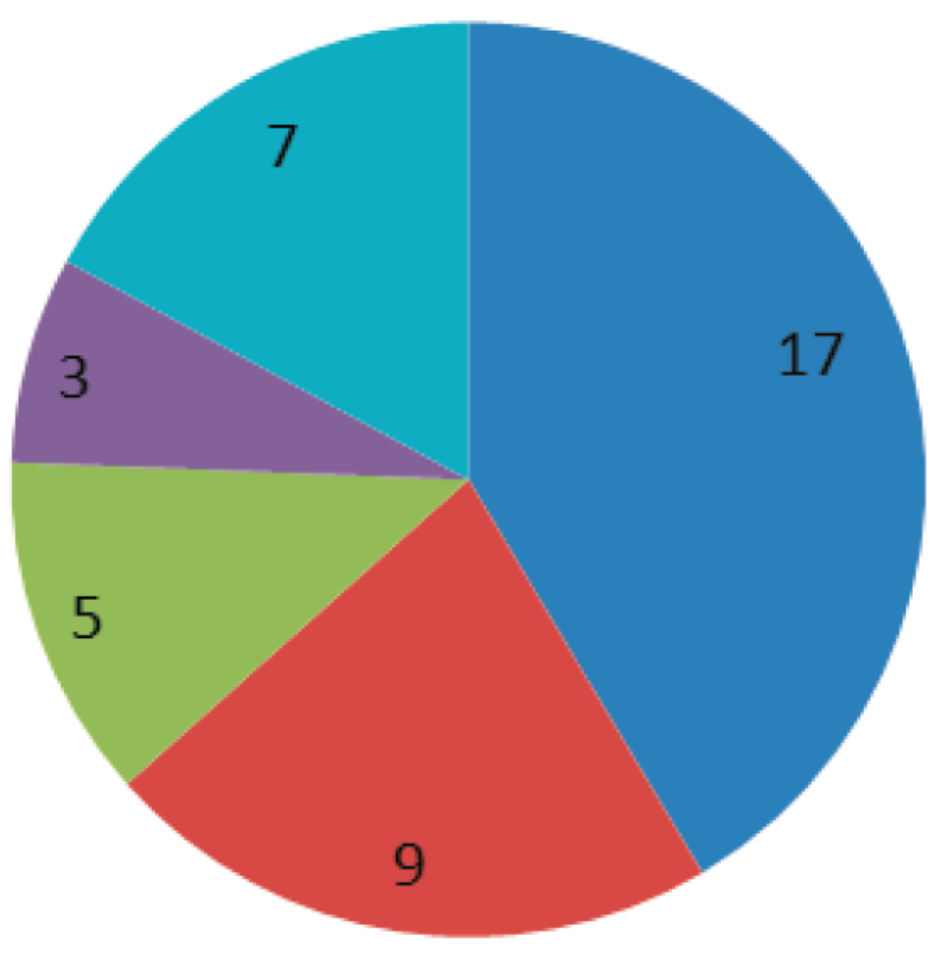

\section{$\mathrm{A} \square \mathrm{C} \square \mathrm{D} \square \mathrm{CRF}$ 10_CD URF}

\section{Figure 3}

Subtypes distribution of isolates from 41 patients. The numbers represent the isolates per subtype. Subtype was determined using Rega subtyping tool version 3 (Pineda-Peña et al., 2013). CRF = circulating recombinant form. URF = unique recombinant form, consisted of CRF 10 CD_D (3), A1_C (1), C_D (1) and D_A1 (2) recombinants. 


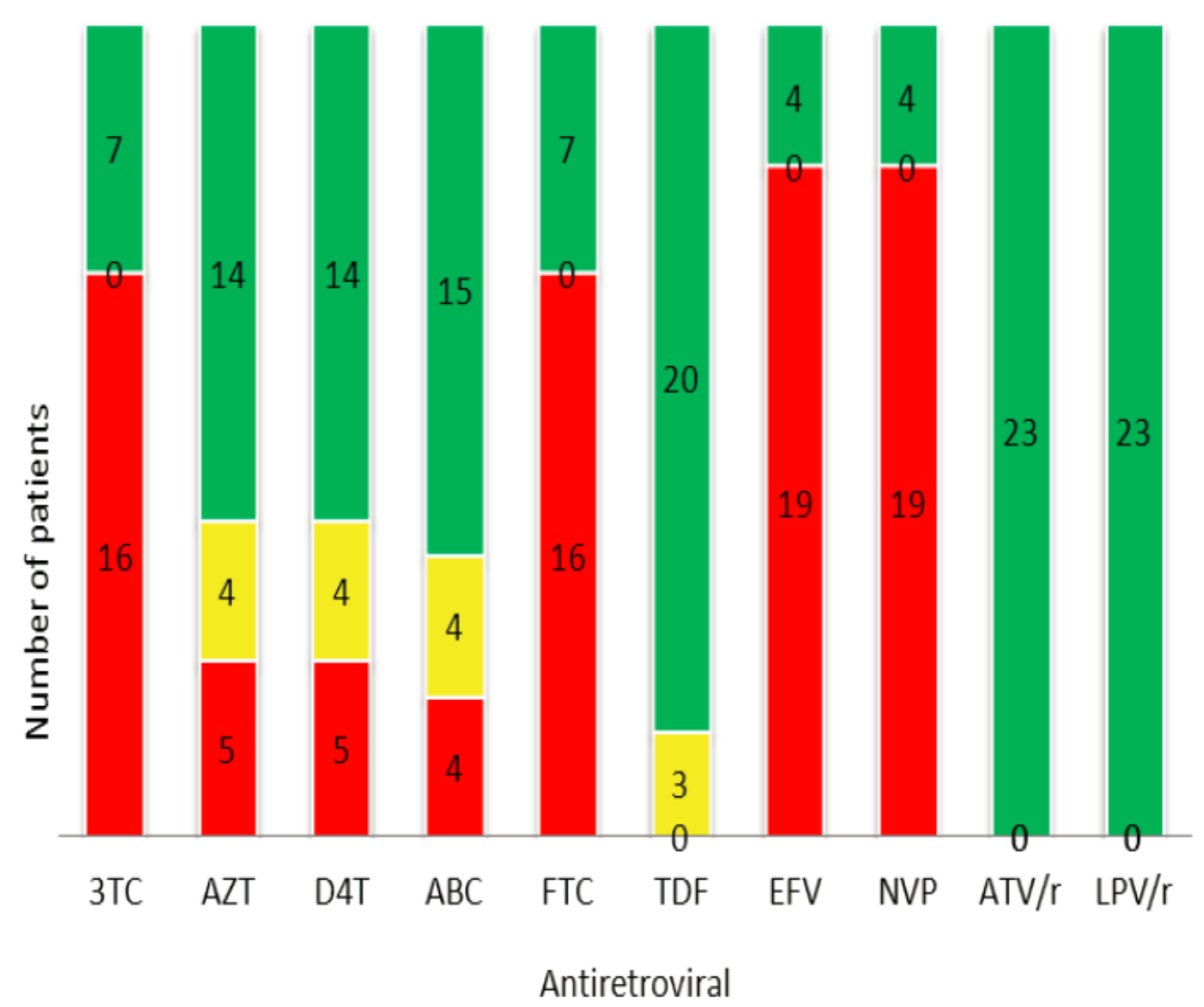

Resistant Intermediate resistant $\quad$ Susceptible

Figure 4

Proportion of drug resistance to antiretrovirals among successfully genotyped patients failing their first-line regimen in Tanzania Genotypic interpretation according to Rega algorithms ( $v$ 8.0.1) 3TC = lamivudine, $A B C=$ abacavir, AZT = zidovudine, D4T = stavudine, FTC = emtricitabine, $T D F=$ tenofovir disoproxil fumarate, EFV = efavirenz, NVP = nevirapine, ATV/r = boosted atazanavir, LPV/ $r=$ boosted lopinavir 